\title{
EFFECTS OF CADMIUM-INDUCED STRESS ON ESSENTIAL OIL PRODUCTION, MORPHOLOGY AND PHYSIOLOGY OF LEMON BALM (MELISSA OFFICINALIS L., LAMIACEAE)
}

\author{
KILIC, S. $^{{ }^{*}}-$ KILIC, M. $^{2}$ \\ ${ }^{1}$ Biology Department, Süleyman Demirel University, Isparta, Turkey \\ phone: +90-246-211-4115 \\ ${ }^{2}$ Environmental Engineering Department, Süleyman Demirel University, Isparta, Turkey \\ phone: +90-246-211-1858 \\ *Corresponding author \\ e-mail:semrakilic@sdu.edu.tr \\ (Received $10^{\text {th }}$ Feb 2017; accepted $19^{\text {th }}$ May 2017)
}

\begin{abstract}
Secondary metabolites, which have an important role in regulating plants' relationship with the environment, are affected by soil pollution. Thus, it is important to describe the mechanism in which lemon balm's (Melissa officinalis L. subsp. officinalis) secondary metabolite accumulation is affected by Cadmium (Cd) stress. For this purpose, lemon balms seedlings that were grown in a controlled environment were exposed to increasing Cd stress and the relationship of lemon balm's growth and development with EO (essential oil) accumulation were investigated. Morphological, anatomical and physiological parameters of plants' that were exposed to Cd significantly decreased in parallel with increasing $\mathrm{Cd}$ concentration. Impairments in growth and development of lemon balm due to increasing $\mathrm{Cd}$ concentrations also affected EO accumulation. However, this destructive effect was most evident on EO accumulation amongst all investigated parameters. Furthermore, amount of EO decreased by $97 \%$, at the highest concentration. In conclusion, Cd might have damaged both the EO producing mechanism and the structures that produce EO by inhibiting plant growth. Therefore it is important to reveal the responses of all parameters which affect EO production of medicinal plants under various stress conditions.
\end{abstract}

Keywords: chlorophyll, ecomorphology, ecophysiology, secondary metabolite, stomata

\section{Introduction}

Lemon balm (Melissa officinalis L. subsp. officinalis) is a perennial, aromatic plant of the Lamiaceae family which is native to Eastern Mediterranan region and Western Asia, and is cultivated in other regions. Its dried leaves have been extensively used in treating various diseases since very old times (Kennedy et al., 2006). Its extract is included in "functional foods" list due to its essential oil content (Čanadanović-Brunet et al., 2008) which has antioxidant (Sousa et al., 2004), antimicrobial (Ceyhan et al., 2012), antidepressant (Petenatti et al., 2011) and antiviral (Allahverdiyev et al., 2004) affects, and is used in the treatment of many diseases, especially cancer (Kamdem et al., 2013). Lemon balm give them to maintain their color and structure for a long time without deterioration of foods by reducing lipid and protein oxidation (Lara et al., 2011). It is also an important raw material used in cosmetic industry (Pérez-Sánchez et al., 2016). Ever increasing industrialization also brings along soil pollution. As one of the most serious problems of industrialization, heavy metal pollution significantly affects all life involved with soil and its impact continues to increase (Bae et al., 2016). Heavy metals like $\mathrm{Pb}, \mathrm{Cu}, \mathrm{Cr}, \mathrm{Zn}, \mathrm{Ni}$ and $\mathrm{Cd}$ negatively affect plant development (Adrees et al., 2015; Curguz et al., 2012; Hayat et al., 2012; Sajid et al., 2011) as well as the content and quantity of secondary metabolites they produce (Biswas et al., 2015; Jesus et al., 
2016; Kunwar et al., 2015). Cd is not essential to plant growth and development (Morsy et al., 2011) and its primary source is anthropogenic (Alloway and Steinnes, 1999). This accelerates the accumulation of this metal in the soil. On the other hand, it's toxic to living beings even at very low concentrations $(1 \mu \mathrm{M})$ due to its high solubility in water and therefore considered as the most dangereous heavy metal (Lux et al., 2011; Seregin and Ivanov, 1998). In spite of this, effects of $\mathrm{Cd}$ on morphological and physiological parameters of lemon balm are still not known. Especially, its effects on EO content and quality of lemon balm were never investigated. However, lemon balm is economically very significant and it's very important to determine the responses of lemon balm's growth, development and secondary metabolite content to environmental conditions. Quantities of linalool, citronellal, geraniol, citral (neral and geranial) and $\beta$-caryophyllene-oxide in lemon balm's essential oil content (Pereira et al., 2014) can vary between different development stages or different organs of the same plant (Moradkhani et al., 2010). They also show significant variance under stress conditions such as drought, salinity, etc (Farahani et al., 2009; Németh-Zámbori et al., 2016). The aim of this study was to determine how lemon balm responded to increasing $\mathrm{Cd}$ concentrations in terms of changes in (1) vegetative growth, (2) stomata and epidermis counts, stomata size, and stomata index of both surfaces of leaves, (3) leaf surface area, (4) total chlorophyll content, and (5) accumulation of EO. In this way, we can determine the adverse effects of Cd on lemon balm's development in parallel with its adverse effects on secondary metabolite accumulation.

\section{Materials and Methods}

\section{Experimental design}

Uniform, two-weeks old lemon balm seedlings (Melissa officinalis L.) purchased from a commercial company (Mersin, Turkey) were used in the experiment. Equal number of seedlings (5) were placed in plastic pots $(20 \mathrm{~cm}$ diameter) filled with vermiculite and perlite $(1: 1 ; \mathrm{v} / \mathrm{v})$, in three replicates. They were grown in a greenhouse under controlled temperature $\left(24{ }^{0} \mathrm{C} \pm 2 / 18{ }^{0} \mathrm{C} \pm 2\right)$, humidity $(40 \pm 10 \%)$, photoperid (16/8h light/dark) and light intensity $\left(160 \mu \mathrm{mol} / \mathrm{m}^{-2} / \mathrm{s}^{-1}\right)$. Hoagland's nutrient solution (1/2 strength) was provided to seedlings every three days for two weeks. Following this, each pot was irrigated every 5 days with half strength of Hoagland's nutrient solution containing various levels of cadmium chloride $\left(\mathrm{CdCl}_{2} .5 \mathrm{H}_{2} \mathrm{O}\right)(0,10,20,30 \mathrm{mg} / \mathrm{kg})$. Experiments were designed in a completely randomized manner with three replicates. After six months, the plants were collected to measure all morphological, anatomical and physiological parameters.

\section{Morphological parameters}

Plant heights was accurately measured by graph paper. Leaf areas were determined using the method of Pandey and Singh (2011). For this purpose, about 10 leaves from each application were seperated from their stems. The leaves were laid out on graph paper and the area of the paper covered by the outlines of the leaves were cut and weighted. Also, $1 \mathrm{~cm}^{2}$ from the same graph paper was cut and weighed. The leaf area was calculated using the Equation 1.

$$
L A=\frac{\mathrm{x}}{\mathrm{y}}
$$


where, $x$ : Weight of the graph paper covered by the leaf outline

$y$ : Weight of $1 \mathrm{~cm}^{2}$ of the same graph paper

\section{Anatomical parameters}

Epidermal tissues stripped from superficial sections of leaves were used to determine the number and sizes of the stomata $(s)$ and epidermis cells $(e)$ of upper (adaxial) and lower (abaxial) surfaces. Stomata and epidermal cells were counted in each field (50 microscopic field) at independent measurement $\left(1 \mathrm{~mm}^{2}\right)$ for upper (USI) and lower (LSI) surfaces of leaves. Stomatal indices (SI) were calculated according to Rengifo et al. (2002) using the Equation 2.

$$
S I=\left[\frac{\text { Total stomata number }}{\text { Total stomata number+Total epidermis cell number }}\right] \times 100
$$

Stomata sizes (length and width) of both surfaces of leaves were measured using an ocular micrometer under light microscope (40 X object and $10 \mathrm{X}$ ocular), calibrated and determined as $\mu \mathrm{m}$.

\section{Total chlorophyll content}

50 leaves from each application were used to determine the total chlorophyll content with a chlorophyll meter (Minolta SPAD-502 Chlorophyll Meter, Minolta Co. Ltd., Japan). Then, pigment degradation was calculated using the obtained data according to Um and Kirdmanee (2009).

\section{Total EO content}

After six mounths, the plants were harvested and the leaves belonging to each application were air-dried at room temperature $\left(22^{\circ} \mathrm{C} \pm 2\right)$ and then cut in small pieces. These pieces were hydrodistillated for 4 hours $\left(105{ }^{\circ} \mathrm{C}\right)$ in a Clevenger apparatus to obtain EOs. The amount of extracted EO was calculated as the volume (in $\mathrm{ml} / 100 \mathrm{~g}$ ) relative to the dry matter $(100 \mathrm{~g})$.

\section{Statistical analysis}

Experimental data were analyzed to evalute statistical differences concerning morphological, anatomical and physiological among application with one-way analysis of variance (ANOVA). Differences among the mean values of the experimental data were compared with Least Significant Difference (LSD) at $\mathrm{P} \leq 0.05$ by Duncan's multiple range test. Data in the figures indicate mean values \pm standard errors (SD) based on three replicates for each application.

\section{Results}

Morphological, anatomical and physiological changes in $\mathrm{Cd}$ treated lemon balm were determined by measuring growth parameters at three $\mathrm{Cd}$ concentrations for 90 days. Height of the plant was different between applications (Fig. 1). While the impact of Cd on the plant height at the lowest Cd concentration was very little (decrease by $14 \%$ ), it was maximum at the highest $\mathrm{Cd}$ concentration (decrease by $73 \%$ ). The statistical 
analysis performed to the data showed that the plant height was significantly decreased by $\mathrm{Cd}$ experiments used, and this decrease in the plant height was statistically significant $(\mathrm{P} \leq 0.05)$.

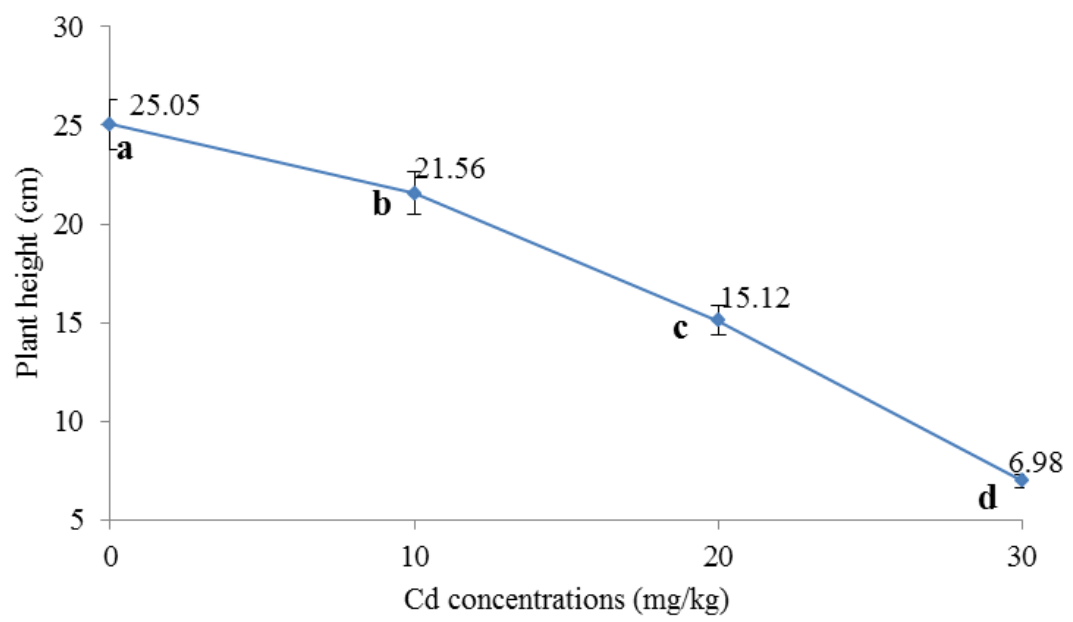

Figure 1. Changes in the plant height of lemon balm under different $C d$ concentrations. Data represent the means and vertical bars indicate the standard error. Different letters indicate significance $(P \leq 0.05)$

Morphological and anatomical changes in lemon balm seedlings exposed Cd stress were determined by examining its leaf parameters. Stomata and epidermis counts, and stomata sizes (length and width) of lower (Fig. 2) and upper (Fig. 3) surfaces of lemon balm leaves were significantly affected by Cd stress. For example, stomata count of the lower surfaces of lemon balm leaves treated with 10,20 , and $30 \mathrm{mg} / \mathrm{kg}$ of $\mathrm{Cd}$ were decreased by $23 \%, 44 \%$, and $73 \%$, respectively, in a dose-dependent manner $(\mathrm{P} \leq 0.05)$. While the epidermis count of similar surfaces decreased by $9 \%$ at $10 \mathrm{mg} / \mathrm{kg} \mathrm{Cd}$ concentration, it decreased by $59 \%$ at $20 \mathrm{mg} / \mathrm{kg}$, and $71 \%$ at $30 \mathrm{mg} / \mathrm{kg}$, compared to control (Fig. 2a). Stomata sizes (length/width) also decreased with increasing Cd concentrations. Furthermore, at the highest $\mathrm{Cd}$ concentration the same parameter decreased by $16 \%$, compared to control $(\mathrm{P} \leq 0.05)$ (Fig. $2 b)$.

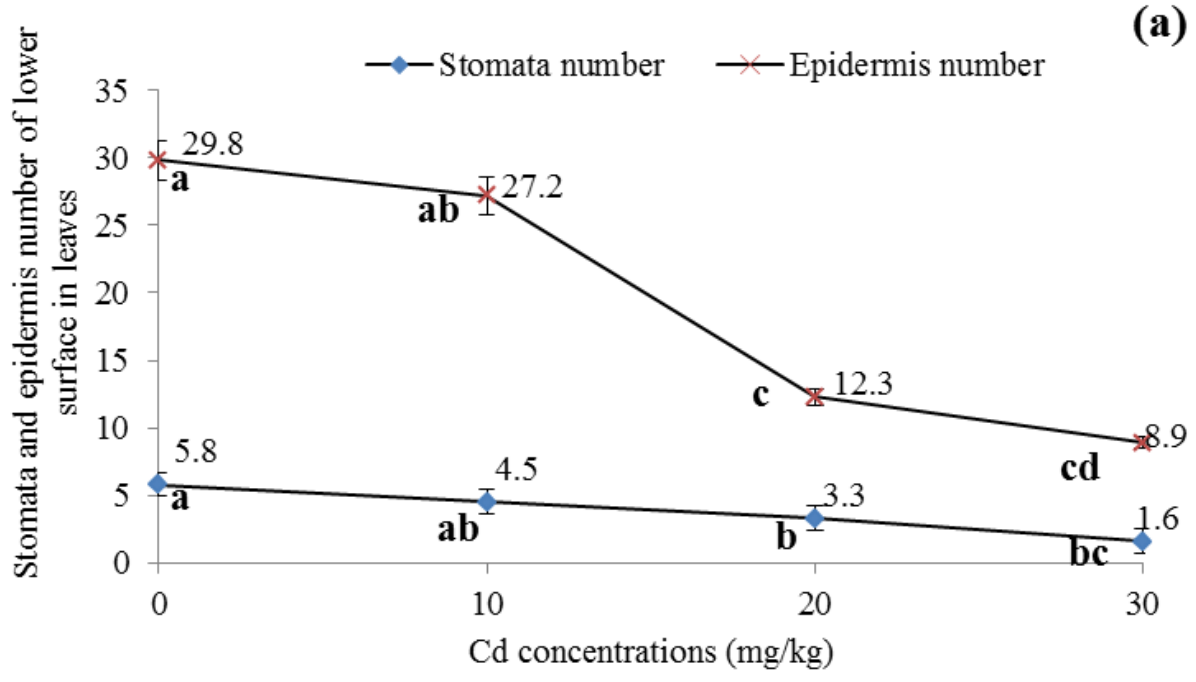


(b)

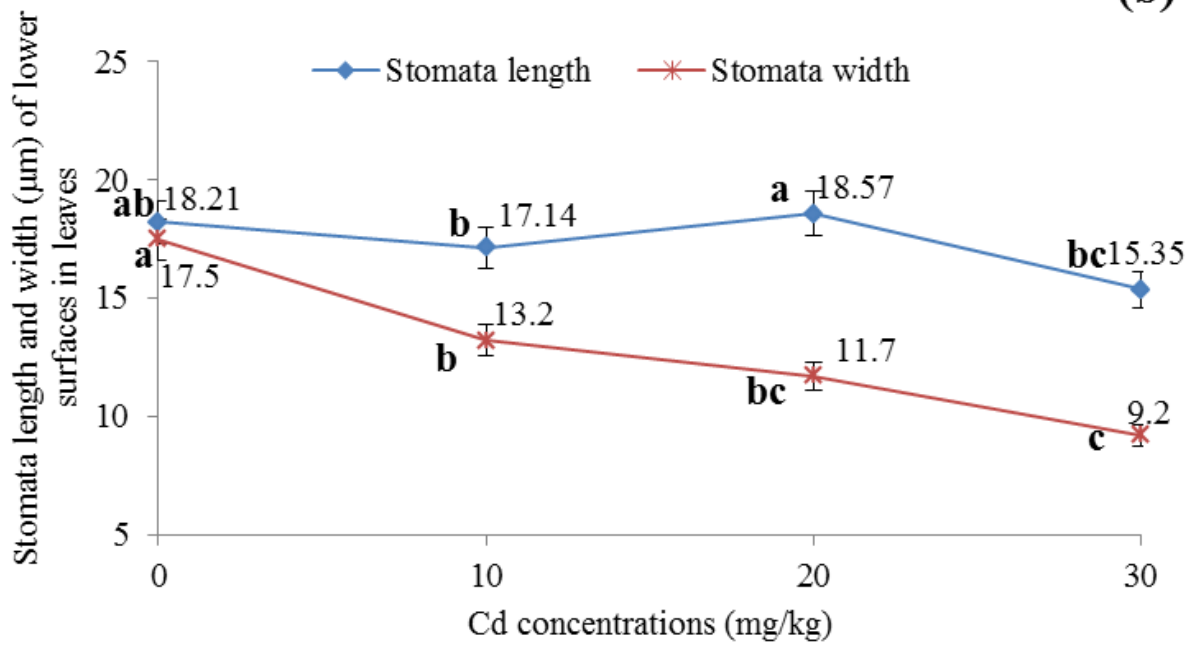

Figure 2. Comparison of stomata properties on lower surfaces of lemon balm leaves exposed to $C d$ stress; Stomata and epidermis counts (a), Stomata length and width (b). Data represent the means and vertical bars indicate the standard error. Different letters indicate significance $(P \leq 0.05)$

The responses of the parameters examined on the lower surface of the lemon balm leaves in Cd stress, similarly responses were observed on upper surfaces. Epidermis counts were decreased by $4 \%, 34 \%, 38 \%$, and stomata counts were decreased by $26 \%$, $55 \%, 78 \%$ at 10, 20, and $30 \mathrm{mg} / \mathrm{kg} \mathrm{Cd}$ concentrations, compared to control (Fig. 3a). Stomata sizes (length/width) also decreased with increasing Cd contentration (Fig. $3 b$ ).

Cd stress affected stomata index (Fig. 4) and leaf surface area (Fig. 5) parameters along with changes in stomata and epidermis cell counts on both of the leaf surfaces. Stomata indices of lower and upper surfaces decreased by 5\%,11\%, 42\% and $23 \%$, $26 \%, 57 \%$, respectively, with increasing concentration $(\mathrm{P} \leq 0.05)$. Leaf surface area was also decreased by $51 \%, 63 \%, 67 \%$ when exposed to $10,20,30 \mathrm{mg} / \mathrm{kg}$ of $\mathrm{Cd}$, respectively.

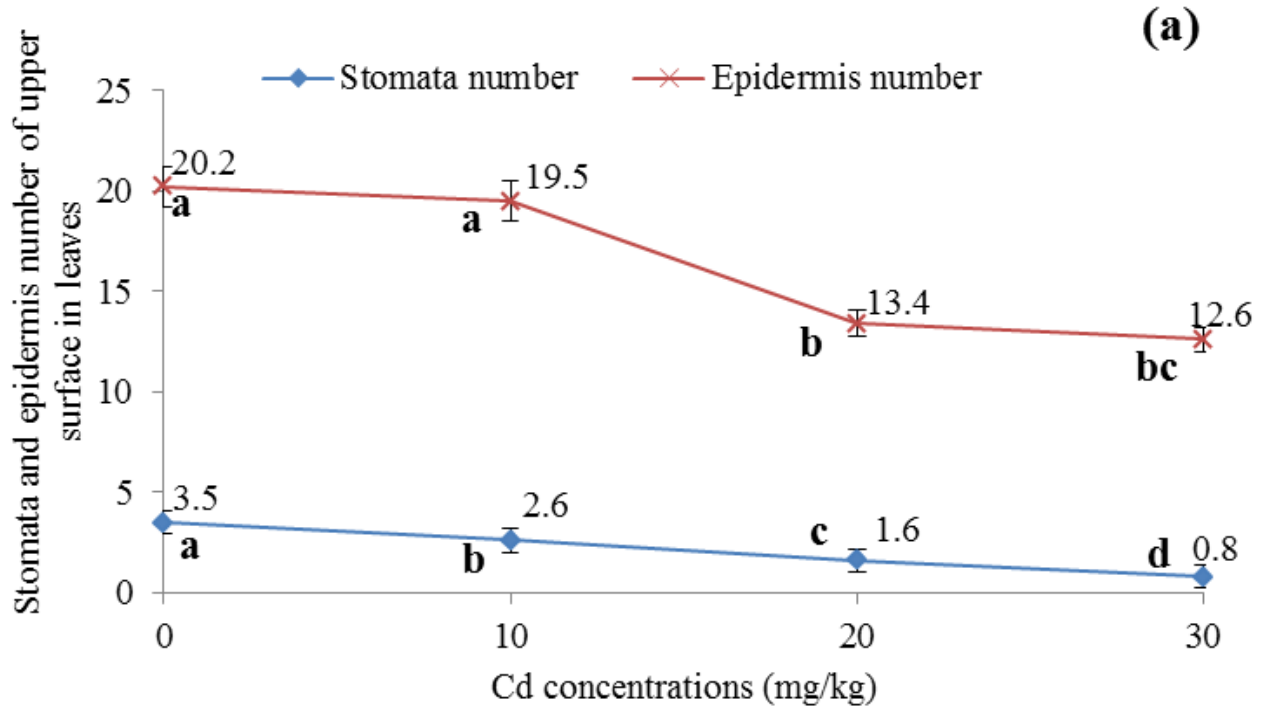




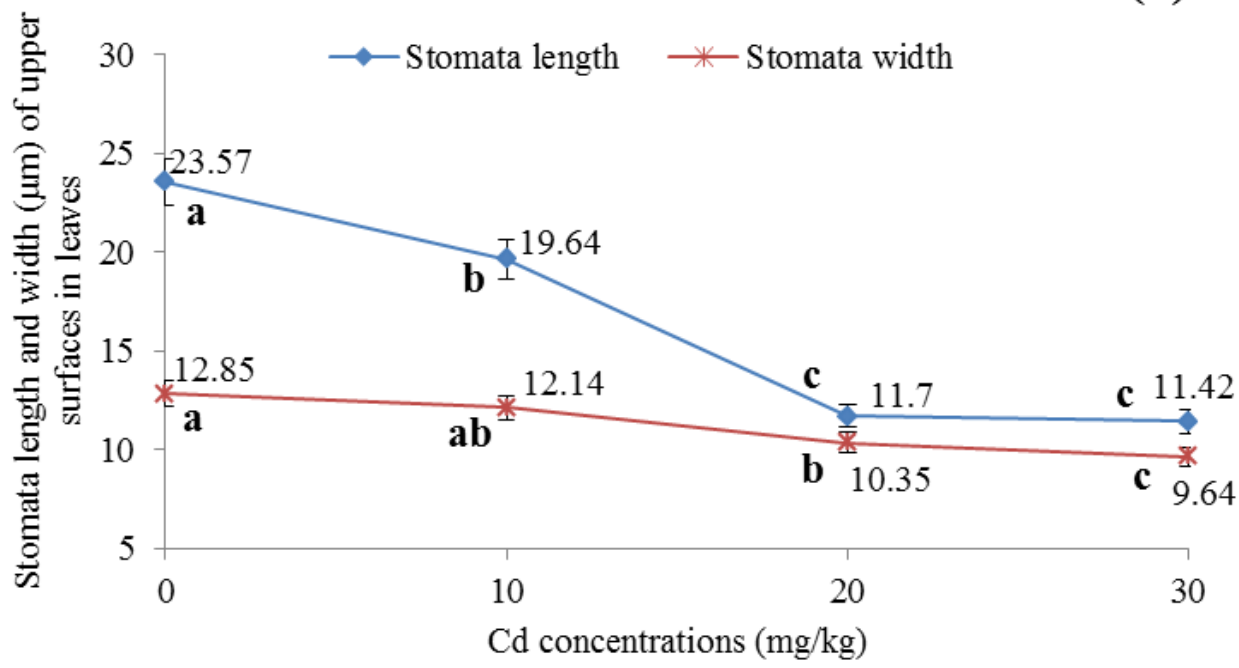

Figure 3. Comparison of stomata properties on upper surfaces of lemon balm leaves exposed to $C d$ stress; Stomata and epidermis counts (a), Stomata length and width (b). Data represent the means and vertical bars indicate the standard error. Different letters indicate significance $(P \leq 0.05)$

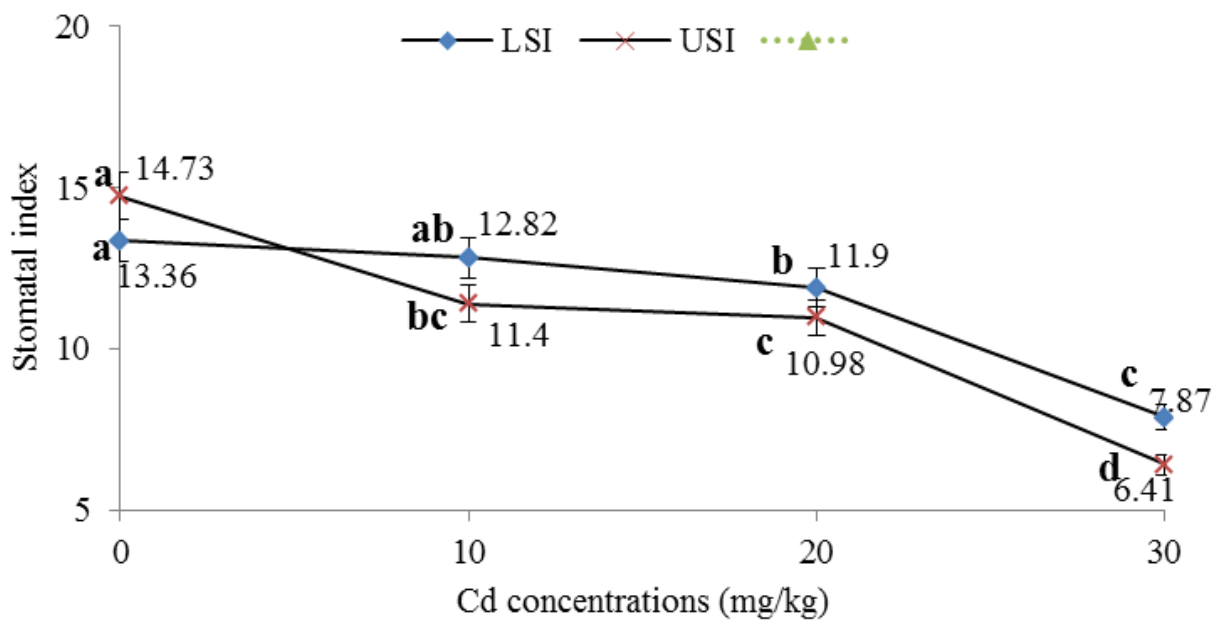

Figure 4. Stomatal indices of lower (LSI) and upper (USI) leaf surfaces of lemon balm at increasing Cadmium concentrations. Data represent the means and vertical bars indicate the standard error. Different letters indicate significance $(P \leq 0.05)$

Photosynthetic pigment contents of lemon balm plants treated with increasing concentrations of $\mathrm{Cd}$ over 90 days were determined, and significant differences were observed, compared to control. This difference to be statistically significant was identified as a decrease total chlorophyll content $(\mathrm{P} \leq 0.05)$. On the other hand, chlorophyll degradation showed an inverse correlation with total chlorophyll content. While total chlorophyll content decreased with increasing $\mathrm{Cd}$ concentrations, chlorophyll degradation increased in all treatments, accorging to the control (Fig. 6). For example, Total chlorophyll content decreased by 5\%, 24\%, $72 \%$ whereas 
chlorophyll degradation increased by $76 \%, 80 \%, 94 \%$ at $10,20,30 \mathrm{mg} / \mathrm{kg}$, respectively, compared to control $(\mathrm{P} \leq 0.05)$.

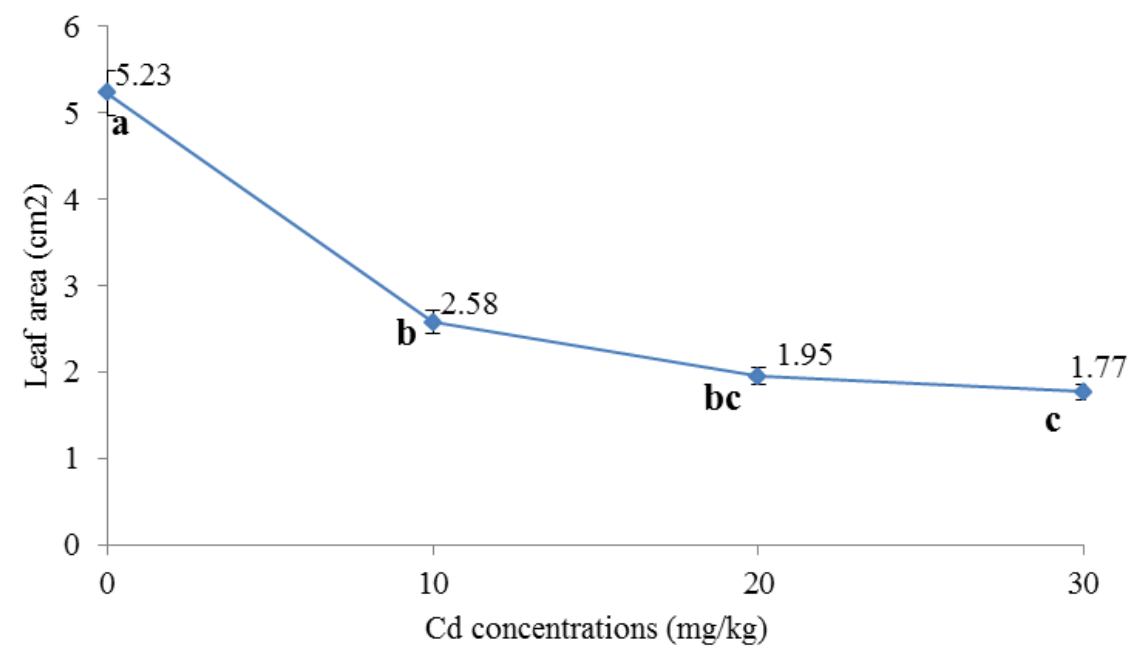

Figure 5. Leaf area of lemon balm at increasing Cadmium concentrations. Data represent the means and vertical bars indicate the standard error. Different letters indicate significance $(P \leq 0.05)$

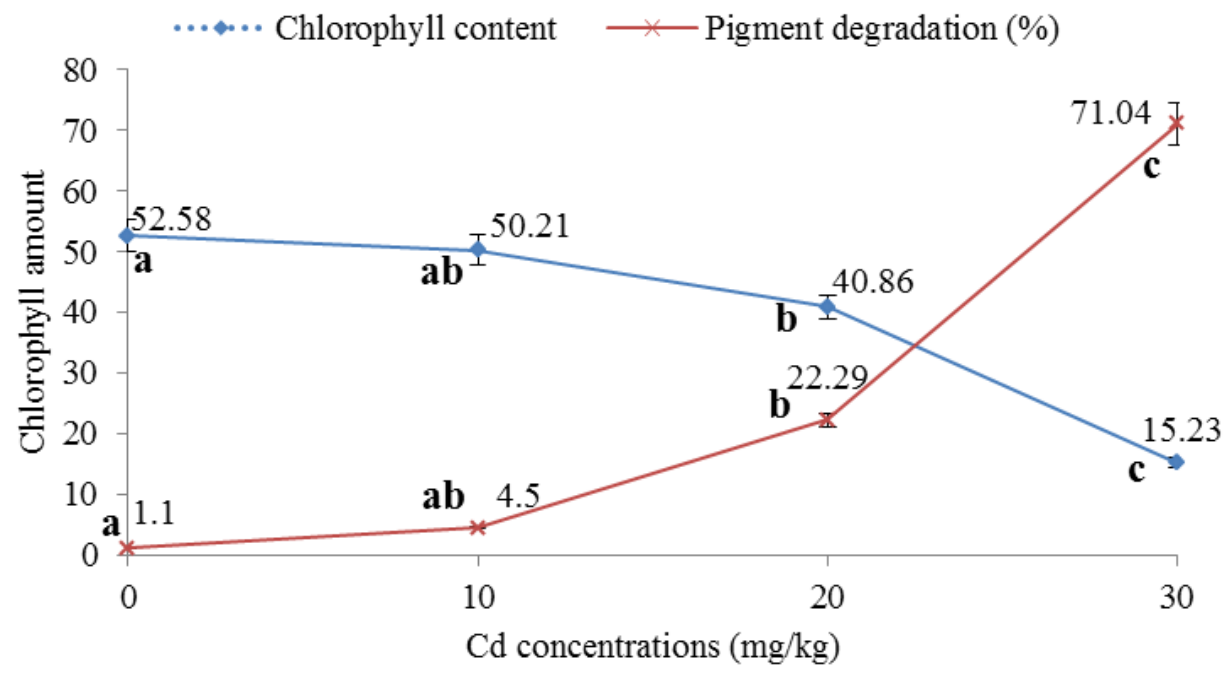

Figure 6. Total chlorophyll amount of lemon balm leaves at increasing Cd concentrations. Data represent the means and vertical bars indicate the standard error. Different letters indicate significance $(P \leq 0.05)$

Toxic effects of $\mathrm{Cd}$ on $\mathrm{EO}$ content were examined by measuring $\mathrm{EO}$ amount, compared with control treatment (Fig. 7). There was a strong negative correlation between the levels of EO amount and $\mathrm{Cd}$ concentration $(\mathrm{P}<0.05)$. For example, EO amount was decreaced by $22 \%, 70 \%, 97 \%$ exposed to $10,20,30 \mathrm{mg} / \mathrm{kg}$ of $\mathrm{Cd}$ respectively, compared to the control. The most destructive effect of $\mathrm{Cd}$ on the EO amount of lemon balm was observed at $20 \mathrm{mg} / \mathrm{kg}$ concentration (69\%). 


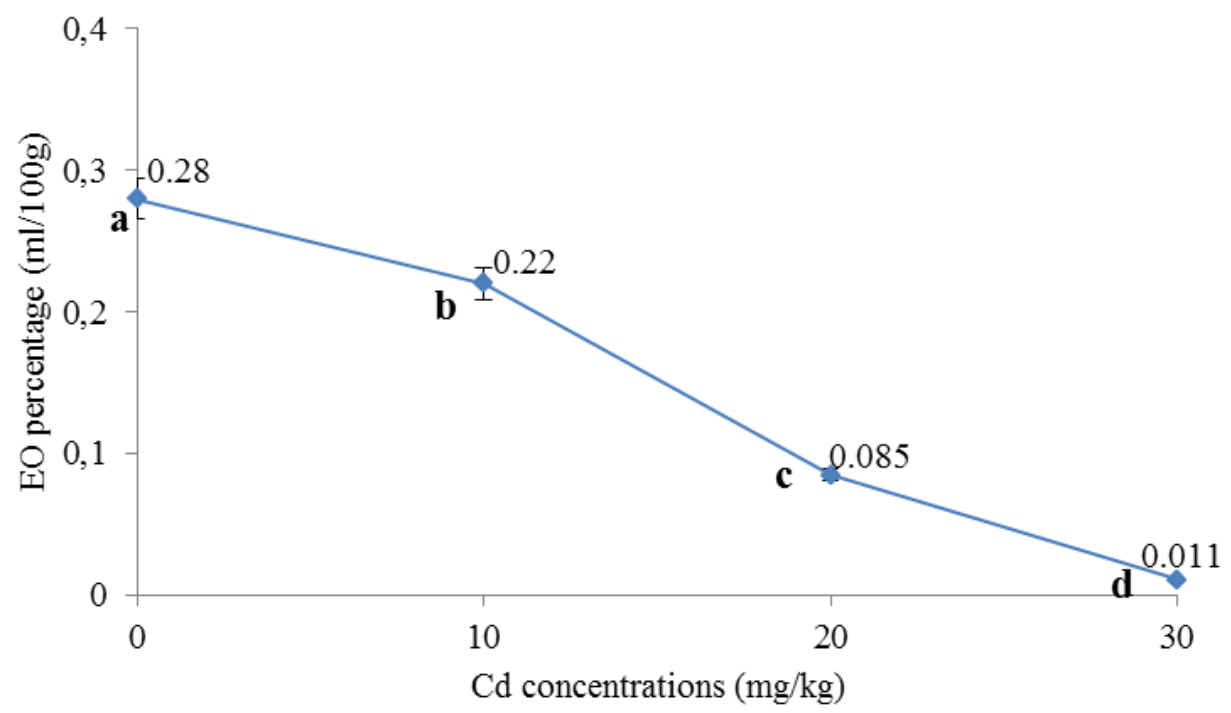

Figure 7. Changes in essential oil (EO) amount of lemon balm at increasing Cd concentrations. Data represent the means and vertical bars indicate the standard error. Different letters indicate significance $(P \leq 0.05)$

\section{Discussion}

We determined the relationship between increasing $\mathrm{Cd}$ stress, and changes in morphological, anatomical and physiological parameters and secondary metabolite amount of lemon balm in each treatment medium. Plant height significantly decreased with increasing $\mathrm{Cd}$ concentrations in the growth medium $(\mathrm{P} \leq 0.05)$. Especially at the highest $\mathrm{Cd}$ concentration plant height decreased by $73 \%$, compared to control. Inhibitory effect of $\mathrm{Cd}$ on the growth of higher plants (Perveen et al., 2016) were also observed for lemon balm. Similar results were observed for alfafa exposed to copper stres. Heavy metals negatively affected not only the plant growth but also nutrient content and enzyme activity (Hong et al., 2015). Cd directly or indirectly affects photosynthesis by reducing or preventing the uptake of elements like $\mathrm{Zn}, \mathrm{Fe}$ and $\mathrm{Cu}$, and in turn blocking enzyme activation and respiration (Seregin and Ivanov, 2001). Therefore, destructive effects of heavy metals on some physiological processes of plants such as photosynthesis, water relations, and mineral nutrition (Zouari et al., 2016) might result in a decrease in plant growth (Anjum et al., 2016a; Hu et al., 2015). Various heavy metals including Cd prevents the uptake of required elements (Shanker et al., 2005), therefore Cd stress inhibited lemon balm's growth. On the other hand, the decrease in growth of lemon balm plants can be explained by suppression of macro/micro element transport under Cd stress (Smiri, 2011), and changes in plant height may be caused by the phytotoxic effects of $\mathrm{Cd}$ accumulation. Moreover, there is a positive correlation between trace element uptake and EO production of lemon balm (Németh-Zámboriné et al., 2016; Sussa et al., 2016). Thus, by preventing nutrient uptake, $\mathrm{Cd}$ accumulation may not only inhibit lemon balm's growth, but also negatively affect secondary metabolite production. Because, changes in plant growth caused by various factors also affect the quantity of secondary metabolites (Cappellari et al., 2013).

Stomata, known as the gas exchange centers, help plants to adapt to environment by altering their numbers and sizes (Aasamaa and Sõber, 2011). Especially, variation in their density and sizes under stress conditions (Negi et al., 2014) is an important 
indication of the impact of the stress factor on the plant (Esmaeilpour et al., 2016). As the duration and degree of the stress increases, these structures gradually degrade, and a morphological, physiological and biochemical decay process which ends with the plant's death begins (Shahid et al., 2017). In the present study, the number of stomata on both surfaces of the lemon balm leaves decreased parallel to the increase in the concentration of $\mathrm{Cd}$. Continuity of vital processes or adaptation to the environment of plants' exposed to stress condititions is possible with reducing stomatal aperture number (Zandalinas et al., 2016). In our study, stomatal aperture number decreased with increasing Cd stress, and this can be tought as one of the lemon balm's responses to the stress. Because, Cd stress causes irregular in mitotic activity (Fusconi et al., 2007; Xu et al., 2009), so their number decreases. At the same time, since heavy metal stress causes degredation of some fundamental structures that play important roles in mitotic activity (Eleftheriou et al., 2015), Cd stress can decrease the density of stomata derived from epidermis cells on both surfaces of lemon balm leaves by disrupting their mitotic activity. A similar effect was observed in the amount of epidermis cells of lower surfaces of leaves. In fact, increasing $\mathrm{Cd}$ concentrations affected the epidermis count of the lower surfaces more than the stomata count. Especially at $20 \mathrm{mg} / \mathrm{kg} \mathrm{Cd}$ concentration stomata amount decreased by $44 \%$ while the amount of epidermis cells decreased by $59 \%$, compared to control $(\mathrm{P} \leq 0.05)$. It is worth noting that while one would expect a decrease in cell counts with increasing $\mathrm{Cd}$ concentrations, the most destructive effect on the epidermis count was observed at $20 \mathrm{mg} / \mathrm{kg}$ concentration. There was a negative correlation between stomata sizes of lower surfaces of the leaves and $\mathrm{Cd}$ concentrations (except for $20 \mathrm{mg} / \mathrm{kg} \mathrm{Cd}$ concentration). Increasing $\mathrm{Cd}$ concentrations caused similar reductions in all investigated parameters of lemon balm leaves on the upper surfaces. Especially, with a 32\% reduction in epidermis count, 20 $\mathrm{mg} / \mathrm{kg} \mathrm{Cd}$ was determined as the most destructive concentration. Moreover, while the highest applied $\mathrm{Cd}$ concentration affected stomata count of the upper surfaces $(78 \%)$ more than the lower surfaces (73\%); it was quite the opposite for epidermis cell count. Stomata sizes on the upper surfaces of the leaves also decreased with increasing $\mathrm{Cd}$ stress. At the highest $\mathrm{Cd}$ concentration, stomata width and length decreased by $25 \%$ and $52 \%$, respectively, compared to control $(\mathrm{P} \leq 0.05)$. On the other hand, the most devastating affect of $\mathrm{Cd}$ on stomata length was observed at $20 \mathrm{mg} / \mathrm{kg}$ concentration with a $41 \%$ decrease. Stomatal apertures are one of the most important components of photosynthesis and transpiration mechanism (Assmann and Jegla, 2016). Stress conditions lead to changes in the amount and sizes of these apertures and in turn these changes negatively affect plants. Cd adversely affected stomata sizes on both upper and lower surfaces. This effect was most noticeable in the stomata lengths on upper surfaces of the leaves (52\% decrease) at the highest Cd concentration (stomata lengths decreased by $16 \%$ on lower surfaces $)(\mathrm{P} \leq 0.05)$. Photosynthetic gas exchange is more sensitive to stress factors on upper surfaces than lower surfaces (Zhang et al., 2016). In our study, it was clear that the plant growth and development mechanism was adversely affected due to the decrease of photosynthetic gas exchange caused because $\mathrm{Cd}$ stress affected stomatal structures (stomata amount and sizes) more on the upper surfaces of the leaves than on the lower surfaces. Because stomata and epidermis cell counts decreased on both surfaces of leaves, stomatal index also decreased. Especially, at the highest Cd concentration stomatal index of upper surface decreased by $55 \%(\mathrm{P} \leq 0.05)$. Stomata undergoes important changes to make it possible for the plant to adapt to various environmental stress factors such as heat, salinity, heavy metals and water scarcity. 
Carbondioxide and water vapour resistance are related to stomatal index and stomata sizes (width/length) (Kaiser et al., 2015), and it is known that changes in stomatal parameters affect the amount of water and gas exchange in the leaves (Hsie et al., 2015), and stomatal responses may limit the photosynthesis (Yamori et al., 2016a). There is a positive correlation between net $\mathrm{CO}_{2}$ assimilation and EO production (Elhindi et al., 2016; Letchamo et al., 1995; Sangwan et al., 2001). Therefore, the linear relationship between gas exchange rate (Xu and Zhou, 2008) and photosynthesis mechanism can also be established between gas exchange and EO synthesis (Athar et al., 2016). When environmental $\mathrm{CO}_{2}$ concentration was increased seconder metabolite content of Robinia pseudoacacia L. grown in soil polluted with $\mathrm{Cd}$ and $\mathrm{Pb}$ also increased (Jia et al., 2016). Furthermore, changes in the stomata and epidermis counts also affected the leaf surface area. Areas of both surfaces of lemon balm decreased in parallel with stomatal index. Similar results were observed for almond leaves edildi (Elloumi et al., 2014). On the other hand, the positive relationship between leaf surface area and the amount of hairs per unit area (Rehman et al., 2016) also affects the density of glandular hairs which are the EO secretion centers (Biswas et al., 2015; Tiwar, 2016). This is an indication that in parallel with the decrease in lemon balm's surface area, the amount of digiform, peltate and capitate glandular trichomes that secrete EO will also decrease under $\mathrm{Cd}$ stress (Chwil et al., 2016). Furthermore, it was reported that leaf surface area is also significantly correlated to yield of the plant (Pandey et al., 2016; Patel and Patra, 2015).

Photosynthetic apparatus are a very sensitive parameters to heavy metal stress (Hayat et al., 2012). Therefore, decrease in chlorophyll content is an important determinant of metal toxicity (Hassan et al., 2017). Total chlorophyll content of the tissues of lemon balm in the control group was the highest (52.58). Lemon balm tissues exposed to the highest $\mathrm{Cd}$ concentration had the lowest total chlorophyll content (15.23). We think that the prevention of uptake and transportation of microelements that play an important role in pigment synthesis by heavy metals (Das et al., 1997) may be the reason why lemon balm's chlorophyll content decreased under Cd stress. In a similar study, conducted on maize, increasing $\mathrm{Cd}$ concentrations led to a significant decrease in chlorophyll concentration (Akhtar et al., 2016). Chlorophyll harvests the light energy and converts it to chemical products and is a very important molecule that ensures the growth, development and differentiation of the plant. Photosynthetic pigments are one of the main components of the photosynthesis mechanism (Mishra et al., 2007; Stewart and Globig, 2016) and any change in their amount and structures (Meier et al. 2011) will destroy this mechanism (Doganlar, 2012), and disturb the morphological, physiological and biochemical reactions (Wieczorek and Wieczorek, 2007). On the other hand, since there is a positive correlation between photosynthetic pigment and EO amounts (Batista et al.,2016), and the inhibition of chlorophyll production by heavy metal stress leads to a significant decrease in metabolite production (Okem et al., 2015). Therefore, chlorophyll degretation is an important indicator used for determining the effects of various stress factors on plants (Aiamla-or et al., 2010). Cd damages chloroplast metabolism by greatly inhibiting chlorophyll biosynthesis (De Filippis and Ziegler, 1993; Gill et al., 2012). We observed this in our study; as Cd amount of the medium increased, chlorophyll degradation also increased. As the effects of $\mathrm{Cd}$ increase, while chlorophyll content decreases, chlorophyll degradation increases. This is an indication that the rate of photosynthesis in plants may decrease. Because, the treatment had adverse effects on photosynthetic process by decreasing chlorophyll content, and chlorophyll content was found to be the lowest at the highest concentration of $\mathrm{Cd}$. 
Changes in EO accumulation of lemon balm exhibited inverse relationships with increased $\mathrm{Cd}$ concentrations. Changes in the growth, leaf parameters and chlorophyll content of lemon balm grown under Cd stress for 90 days also affected the plant's EO synthesis mechanism. This mechanism was affected worse than all other investigated parameters by the highest $\mathrm{Cd}$ concentration. While reducing plant growth, heavy metal stress also affects plants' potential to synthesize bioactive compounds (Okem et al., 2016). A similar result was obtained for Mentha crispa exposed to $\mathrm{Pb}$ stress, and $\mathrm{Pb}$ stress affected EO content more than all other investigated parameters (Raquel et al., 2015). Secondary metabolite production in plants is affected by environmental factors such as salt (Kasrati et al., 2014; Yu et al., 2015), water (Németh-Zámbori et al., 2016), heavy metals (Sosa et al., 2016), and secondary metabolite content decreases in parallel with plant growth and development (Islam et al., 2016). On the other hand, high concentrations of $\mathrm{Cd}$ in the soil negatively affects trichomes' structural integrity (Wolff et al., 2012). Changes in lemon balms growth and development reduces the amount of EO synthesizing structures especially in the leaves (Moradkhani et al., 2010). In this study, at the highest $\mathrm{Cd}$ concentration, the experimental group was observed to have $73 \%$ decrease in plant height; $73 \%$ and $71 \%$ decreases in stomata and epidermis, $16 \%$ and $48 \%$ decreases stomata length and width on the lower surfaces of the leaves, respectively; $78 \%$ and $38 \%$ decreases in number of stomata and epidermis, $52 \%$ and $25 \%$ decreases stomata length and width on the upper surface of the leaves, respectively; $42 \%$ and $57 \%$ decrease in stomata index on the lower and upper surfaces of the leaves, respectively; $67 \%$ decrease in leaf area; $72 \%$ decrease in chlorophyll amount with respect to the control group.

Secondary metabolite content of plants are significantly influenced by the genetic character of the plants and various abiotic factors. It also varies between the parts and the developmental stages of the plants (Branislava et al., 2013). Therefore, changes in the morphological and physiological processes causes the variation in the amount and the quality of the essential oils. Secondary metabolites are substances that give plants various advantages in important events such as defense, protection, survival and reproduction that helps them to adapt to the environmental conditions in the ecosystem (Bourgaud et al., 2001). Thus, the amount of these substances per unit increases under stress conditions (Haddadi et al., 2016; Németh-Zámbori et al., 2016). However, stress factors also cause deformations in various growth parameters of plants leading to a decrease in the production of metabolites (Saeidnejad et al., 2016). When plants containing secondary metabolites are exposed to a stress factor, there is a negative correlation between the stress factor and the amount of secondary metabolites but a positive correlation with the amount per unit area of substances that constitute secondary metabolites. We think that the decrease in EO amount with increasing $\mathrm{Cd}$ stress might be the result of the decrease in EO syntesizing structures in parallel with all other investigated parameters of lemon balm and physiological degredation of these structures. Therefore, along with the changes in plant growth and development parameters, morphological and biochemical changes in EO synthesizing structures should also be thoroughly investigated. In light of these results, we can emphasize once more that phytotoxic impacts of heavy metal stress on mankind's future remedies (Tomlinson and Akerele, 2015) should be determined and studies on the subject should be hastened. 


\section{REFERENCES}

[1] Aasamaa, K., Sõber, A. (2011): Stomatal sensitivities to changes in leaf water potential, air humidity, $\mathrm{CO}_{2}$ concentration and light intensity, and the effect of abscisic acid on the sensitivities in six temperate deciduous tree species. - Environmental and Experimental Botany 71: 72-78.

[2] Adrees, M., Ali, S., Rizwan, M., Ibrahim, M., Abbas, F., Farid, M., Rehman, M.Z., Irshad, M.K., Bharwana, S.A. (2015): The effect of excess copper on growth and physiology of important food crops: a review. -Environmental Science and Pollution Research 22: 8148-8162.

[3] Aiamla-Or, S., Kaewsuksaeng, S., Shigyo, M., Yamauchi, N. (2010): Impact of UV-B irradiation on chlorophyll degradation and chlorophyll-degrading enzyme activities in stored broccoli (Brassica oleracea L. Italica Group) florets. - Food Chemistry 120: 645651.

[4] Akhtar, T., Zia-ur-Rehman, M., Naeem, A., Nawaz, R., Ali, S., Murtaza, G., Maqsood, M.A., Azhar, M., Khalid, H., Rizwan, M. (2016): Photosynthesis and growth response of maize (Zea mays L.) hybrids exposed to cadmium stress. - Environmental Science and Pollution Research 1-9 doi: 10.1007/s11356-016-8246-0.

[5] Allahverdiyev, A., Duran, N., Ozguven, M., Koltas, S. (2004): Antiviral activity of the volatile oils of Melissa officinalis L. against Herpes simplex virus type-2. Phytomedicine 11: 657-61.

[6] Alloway, B.J., Steinnes, E. (1999): Anthropogenic Additions of Cd to Soils. - Kluwer Academic Publishers, Dordrecht.

[7] Anjum, S.A., Ashraf, U., Khan, I., Tanveer, M., Saleem, M.F., Wang, L. (2016a): Aluminum and chromium toxicity in maize: implications for agronomic attributes, net photosynthesis, physio-biochemical oscillations, and metal accumulation in different plant parts. - Water, Air, and Soil Pollution 227: 326.

[8] Assmann, S.M., Jegla, T. (2016): Guard cell sensory systems: recent insights on stomatal responses to light, abscisic acid, and $\mathrm{CO}_{2}$ - Current Opinion in Plant Biology 33: 157167.

[9] Athar, H.R., Ambreen, S., Javed, M., Hina, M., Rasul, S., Zafar, Z.U., Manzoor, H., Ogbaga, C.C., Afzal, M., Al-Qurainy, F., Ashraf, M. (2016): Influence of sub-lethal crude oil concentration on growth, water relations and photosynthetic capacity of maize (Zea mays L.) plants. - Environmental Science and Pollution Research. 23: 18320-18331.

[10] Bae, J., Benoit, D.L., Watson, A.K. (2016): Effect of heavy metals on seed germination and seedling growth of common ragweed and roadside ground cover legumes. Environmental Pollution. 213: 112-118.

[11] Batista, D.S., Castro, K.M., Silva, A.R., Teixeira, M.L., Sales, T.A., Soares, L.I., Cardoso, M.G., Santos, M.O., Viccini, L.F., Otoni, W.C. (2016): Light quality affects in vitro growth and essential oil profile in Lippia alba (Verbenaceae). - In Vitro Cellular \& Developmental Biology 52: 276-282.

[12] Biswas, S., Koul, M., Bhatnagar, A.K. (2015): Effect of arsenic on trichome ultrastructure, EO yield and quality of Ocimum basilicum L. - Medicinal Plant Research 5: 6 .

[13] Bourgaud, F., Gravot, A., Milesi, S., Gontier, E. (2001): Production Of Plant Secondary Metabolites; a historical Perspective. - Plant Science 161: 839-851.

[14] Branislava, S., Lakušić, Mihailo, S., Ristić, Violeta, N., Slavkovska, Stojanović, D.L. Dmitar, V.L. (2013): Variations in essential oil yields and compositions of Salvia officinalis (Lamiaceae) at different developmental stages. - Botanica Serbica 37: 127-139.

[15] Canadanović-Brunet, J., Ćetković, G., Djilas, S., Tumbas, V., Bogdanović, G., Mandić, A., Markov, S., Cvetković, D., Čanadanović, V. (2008): Radical scavenging, antibacterial, and antiproliferative activities of Melissa officinalis L. extracts. - Journal of Medicinal Food 11: 1 
[16] Cappellari, L.R., Santoro, M.V., Nievas, F., Giordano, W., Banchio, E. (2013): Increase of secondary metabolite content in marigold by inoculation with plant growth-promoting rhizobacteria. - Applied Soil Ecology 70: 16-22.

[16] Ceyhan, N., Keskin, D., Uğur, A. (2012): Antimicrobial activities of different extracts of eight plant species from four different family against some pathogenic microoorganisms. - Journal of Food, Agriculture and Environment 10: 193-197.

[17] Chwil, M., Nurzyńska- Wierdak, R., Chwil, S., Matraszek, R., Neugebauerová, J. (2016): Histochemistry and micromorphological diversity of glandular trichomes in Melissa officinalis L. leaf epidermis. - Acta Scientiarum Polonorum Hortorum Cultus 15: 153172.

[18] Curguz, V.G., Raicevic, V., Veselinovic, M., Tabakovic-Tosic, M, Vilotic, D. (2012): Influence of heavy metals on seed germination and growth of Picea abies L. Karst. Polish Journal of Environmental Studies 12: 355-361.

[19] Das, P., Samantaray, S., Rout, G.R. (1997): Studies on cadmium toxicity in plants: a review. - Environmental Pollution 98: 29-36.

[20] De Filippis, L.F., Ziegler, H. (1993): Effect of sublethal concentration of zinc, Cd and mercury on the photosynthetic carbon reduction cycle of Euglena. - Journal of Plant Physiology 142: 167-172.

[21] Doganlar, Z.B. (2012): Physiological and genetic responses to pesticide mixture treatment of Veronica beccabunga. - Water, Air and Soil Pollution 223: 6201-6212.

[22] Eleftheriou, E.P., Michalopoulou, V.A., Adamakis, I.D.S. (2015): Aberration of mitosis by hexavalent chromium in some Fabaceae members is mediated by species-specific microtubule disruption. - Environmental Science and Pollution Research 22: 7590-7599.

[23] Elhindi, K.M., El-Hendawy, S., Abdel-Salam, E., Schmidhalter, U., Rahman, S., Hassan A. (2016): Foliar application of potassium nitrate affects the growth and photosynthesis in coriander (Coriander sativum L.) plants under salinity. - Progress in Nutrition 18: 63-73.

[24] Elloumi, N., Zouari, M., Chaari, L., Jomni, C., Rouina, B.B., Abdallah, F.B. (2014): Ecophysiological responses of almond (Prunus dulcis) seedlings to cadmium stress. Biologia 69: 604-609.

[25] Esmaeilpour, A., Labeke, M.C.V., Samson, R., Boeckx, P., Damme, P.V. (2016): Variation in biochemical characteristics, water status, stomata features, leaf carbon isotope composition and its relationship to water use efficiency in pistachio (Pistacia vera L.) cultivars under drought stress condition. - Scientia Horticulturae 211: 158-166.

[26] Farahani, A., Valadabadi, S.A., Daneshian, J., Khalvati, M.A. (2009): Evaluation changing of EO of balm (Melissa officinalis L.) under water deficit stress conditions. Journal of Medicinal Plants Research 3: 329-333.

[27] Fusconi, A., Gallo, C., Camusso, W. (2007): Effects of cadmium on root apical meristems of Pisum sativum L.: cell viability, cell proliferation and microtubule pattern as suitable markers for assessment of stress pollution. - Mutation Research 632: 9-19.

[28] Gill, S.S, Khan, N.A., Tuteja, N. (2012): Cadmium at high dose perturbs growth, photosynthesis and nitrogen metabolism while at low dose it up regulates sulfur assimilation and antioxidant machinery in garden cress (Lepidum sativum L.). - Plant Science 182: 112-120.

[29] Haddadi, B.S., Hassanpour, H., Niknam, V. (2016): Effect of salinity and waterlogging on growth, anatomical and antioxidative responses in Mentha aquatica L. Acta Physiologiae Plantarum. 38: 1-11.

[30] Hassan, Z., Ali, S., Ahmad, R., Rizwan, M., Abbas, F., Yasmeen, T., Iqbal, M. (2017): Biochemical and molecular responses of oil seed crops to heavy metal stress. Government College University Faisalabad, Pakistan.

[31] Hayat, S., Khalique, G., Irfan, M., Wani, A.S., Tripathi, B.N., Ahmad, A. (2012): Physiological changes induced by chromium stress in plants: an overview. - Protoplasma 249: 599-611. 
[32] Hong, J., Rico, C.M., Zhao, L., Adeleye, A.S., Keller, A.A., Peralta-Videa, J.R., GardeaTorresdey, J.L. (2015): Toxic effects of copper-based nanoparticles or compounds to lettuce (Lactuca sativa) and alfalfa (Medicago sativa). - Environmental Science: Processes \& Impacts 17: 177-185.

[33] Hsie, B.S., Mendes, K.R., Antunes, W.C., Endres, L., Campos, M.L.O., Souza, F.C., Santos, N.D., Singh, B., Arruda, E.C.P., Pompelli, M.F. (2015): Jatropha curcas L. (Euphorbiaceae) modulates stomatal traits in response to leaf-to-air vapor pressure deficit. - Biomass and Bioenergy 81: 273-281.

[34] Hu, J., Deng, Z., Wang, B., Zhi, Y., Pei, B., Zhang, G., Luo, M., Huang, B., Wu, W., Huang, B. (2015): Influence of Heavy Metals on Seed Germination and Early Seedling Growth in Crambe abyssinica, a Potential Industrial Oil Crop for Phytoremediation. American Journal of Plant Sciences 6: 150-156.

[35] Islam, F., Yasmeen, T., Arif, M.S., Riaz, M., Shahzad, S.M., Imran, Q., Ali, I. (2016): Combined ability of chromium $(\mathrm{Cr})$ tolerant plant growth promoting bacteria (PGPB) and salicylic acid (SA) in attenuation of chromium stress in maize plants. - Plant Physiology and Biochemistry 108: 456-467.

[36] Jesus, D.S., Azevedo, B.O., Pinelli, M.S., Korn, M.G.A., Neto, A.D.A., Lucchese, A.M., Oliveira, L.M. (2016): Growth and volatile compounds of Martianthus leucocephalus exposed to heavy metal stress. - Ciência Rural 46: 2110-2117.

[37] Jia, X., Zhao, Y., Liu, T., Huang, S. (2016): Elevated $\mathrm{CO}_{2}$ affects secondary metabolites in Robinia pseudoacacia $\mathrm{L}$. seedlings in $\mathrm{Cd}$ - and $\mathrm{Pb}$-contaminated soils. - Chemosphere 160: 199-207.

[38] Kaiser, E., Morales, A., Harbinson, J., Kromdijk, J., Heuvelink, E., Marcelis, L.F.M., (2015): Dynamic photosynthesis in different environmental Conditions. - Journal of Experimental Botany 66: 2415-2426.

[39] Kamdem, J.P., Adeniran, A., Boligon, A.A., Klimaczewski, C.V., Elekofehinti, O.O., Hassan, W., Ibrahim, M., Waczuk, E.P., Meinerz, D.F., Athayde, M.L. (2013): Antioxidant activity, genotoxicity and cytotoxicity evaluation of lemon balm (Melissa officinalis L.) ethanolic extract: Its potential role in neuroprotection. - Industrial Crops and Products 51: 26-34.

[40] Kasrati, A., Jamali, C.A., Bekkouche, K., Wohlmuth, H., Leach, D., Abbad, A. (2014): Plant growth, mineral nutrition and volatile oil composition of Mentha suaveolens subsp. timija (Briq.) Harley cultivated under salt stress conditions. - Industrial Crops and Products 59: 80-84.

[41] Kennedy, D.O., Little, W., Haskell, C.F., Scholey, A.B. (2006): Anxiolytic effects of a combination of Melissa officinalis and Valeriana officinalis during laboratory induced stress. - Phytotherapy Research 20: 96-102.

[42] Kunwar, G., Pande, C., Tewari, G., Singh, C., Kharkwal, G.C. (2015): Effect of heavy metals on terpenoid composition of Ocimum basilicum L. and Mentha spicata L. - Journal of Essential Oil Bearing Plants 18: 818-825.

[42] Lara, M.S., Gutierrez, J.I., Timón, M., Andrés, A.I. (2011): Evaluation of two natural extracts (Rosmarinus officinalis L. and Melissa officinalis L.) as antioxidants in cooked pork patties packed in MAP. - Meat Science 88: 481-488.

[43] Letchamo, W., Xu, H.L., Gosselin, A. (1995): Variations in photosynthesis and essential oil in Thyme. - Journal of Plant Physiology 147: 29-37.

[44] Lux, A., Martinka, M., Vaculı'k, M., White, P.J. (2011): Root responses to cadmium in the rhizosphere: a review. - Journal of Experimental Botany 62: 21-37.

[45] Meier, S., Tzfadia, O., Vallabhaneni, R., Gehring, C., Wurtzel, E.T. (2011): A transcriptional analysis of carotenoid, chlorophyll and plastidial isoprenoid biosynthesis genes during development and osmotic stress responses in Arabidopsis thaliana. - BMC Systems Biology 5: 1-19.

[46] Mishra, K., Rai, U.N., Prakash, O. (2007): Bio-concentration and phytotoxicity of Cd in Eichhornia crassipes. - Environmental Monitoring and Assessment 130: 237-243. 
[47] Moradkhani, H., Sargsyan, E., Bibak, H., Naseri, B., Sadat-Hosseini, M., Fayazi-Barjin, A., Meftahizade, H. (2010): Melissa officinalis L., a valuable medicine plant: A Review. Journal of Medicinal Plants Research 4: 2753-2759.

[48] Morsy, F.M., Hassan, S.H.A., Koutb, M. (2011): Biosorption of Cd (II) and Zn (II) by nostoc commune: isotherm and kinetics studies. - Clean Soil Air Water 39: 680-687.

[49] Negi, J., Hashimoto-Sugimoto, M., Kusumi, K., Iba, K. (2014): New approaches to the biology of stomatal guard cells. - Plant Cell Physiology 55: 241-250.

[50] Németh-Zámbori, E., Szabó, K., Pluhár, Z., Radácsi, P., Inotai, K. (2016): Changes in biomass and essential oil profile of four Lamiaceae species due to different soil water levels. - Journal of Essential Oil Research 28: 391-399.

[51] Németh-Zámboriné, E., Szabó, K., Rajhárt, P., Lelik, L., Bernáth, J. Popp, T. (2016): Effect of nutrients on drug production and essential oil content of Lemon balm (Melissa officinalis L.). - Journal of Essential Oil Bearing Plants 18: 2015.

[52] Okem, A., Stirk, W.A., Street, R.A., Southway, C., Finnie, J.F., Staden, J.V. (2015): Effects of $\mathrm{Cd}$ and $\mathrm{Al}$ stress on secondary metabolites, antioxidant and antibacterial activity of Hypoxis hemerocallidea Fisch. \& C.A. Mey. - Plant Physiology and Biochemistry 97: 147-155.

[53] Okem, A., Moyo, M., Stirk, W.A., Finnie, J.F., Staden, J.V. (2016): Investigating the effect of cadmium and aluminium on growth and stress-induced responses in the micropropagated medicinal plant Hypoxis hemerocallidea. - Plant Biology 18: 805-815.

[54] Pandey, S.K., Singh, H. (2011): A simple, cost-effective method for leaf area estimation. - Journal of Botany 2011: 6.

[55] Pandey, V., Patel, A., Patra, D.D. (2016): Biochar ameliorates crop productivity, soil fertility, essential oil yield and aroma profiling in basil (Ocimum basilicum L.). Ecological Engineering 90: 361-366.

[56] Patel, A., Patra, D.D. (2015): Effect of tannery sludge amended soil on glutathione activity of four aromatic crops: Tagetes minuta, Pelargonium graveolens, Ocimum basilicum and Mentha spicata. - Ecological Engineering 81: 348-352.

[57] Pereira, R.P., Boligon, A.A., Appel, A.S., Fachinetto, R., Ceron, C.S., Tanus-Santos, J.E., Athayde, M.L., Rocha, J.B.T. (2014): Chemical composition, antioxidant and anticholinesterase activity of Melissa officinalis. - Industrial Crops and Products 53: 3445.

[58] Pérez-Sánchez, A., Barrajón-Catalán, E., Herranz-López, M., Castillo, J., Micol, V. (2016): Lemon balm extract (Melissa officinalis, L.) promotes melanogenesis and prevents UVB-induced oxidative stress and DNA damage in a skin cell model. - Journal of Dermatological Science 84: 169-177.

[59] Perveen, S., Shahbaz, M., Iqbal, M., Akram, M.S., Parveen, A., Ali, H.M.M. (2016): Induction of Cadmium Stress Tolerance in Tritıcum Aestıvum L. by Alfalfa Leaf Extract. Applied Ecology and Environmental Research 14:121-136.

[60] Petenatti, M.E., Petenatti, E.M., Vitto, L.A., Téves, M.R., Caffini, N.O., Marchevsky, E.J., Pellerano, R.G. (2011): Evaluation of macro and microminerals in crude drugs and infusions of five herbs widely used as sedatives. - Brazilian Journal of Pharmaceutical Sciences 21: 1144-1149.

[61] Raquel, A.S., Renata, A.S., Alberton, O., Gazim, Z.C., Jr, A.L., Caetano, J., Amorin, A.C., Dragunski, D.C. (2015): Phytoaccumulation and effect of lead on yield and chemical composition of Mentha crispa essential oil. - Desalination and Water Treatment 53: 3007-3017.

[62] Rehman, R., Hanif, M.A., Mushtaq, Z., Mochona, B., Qi, X. (2016): Biosynthetic Factories of essential oils: The Aromatic Plants. - Natural Products Chemistry \& Research 4: 227.

[63] Rengifo, E., Urich, R., Herrera, A. (2002): Water relations and leaf anatomy of the tropical species, Jatropha gossypifolia and Alternanthera crucis, grown under elevated CO2 concentration. - Photosynthetica 40: 397-403. 
[64] Saeidnejad, A.H., Kafi, M., Khazaei, H.R., Pessarakli, M. (2016): Combined effects of drought and UV stress on quantitative and qualitative properties of Bunium persicum. Journal of Essential Oil Bearing Plants 19: 1729 - 1739.

[65] Sajid, M., Ahmad, A., Ashraf, M. (2011): Essential roles and hazardous effects of nickel in plants. - Reviews of Environmental Contamination and Toxicology 214: 125-167.

[66] Sangwan, N.S., Farooqi, A.H.A., Shabih, F., Sangwan, R.S. (2001): Regulation of EO production in plants. - Plant Growth Regulation 34: 3-21.

[67] Seregin, I., Ivanov, V.B. 1998. The transport of Cd and lead ions through root tissues. Russian Journal of Plant Physiology 45: 780-785.

[68] Seregin, I., Ivanov, V.B. (2001): Physiological Aspects of cadmium and lead toxic effects on higher plants. - Russian Journal of Plant Physiology 48: 523-544.

[69] Shahid, M., Dumat, C., Khalid, S., Schreck, E., Xiong, T., Niazi, N.K. (2017): Foliar heavy metal uptake, toxicity and detoxification in plants: A comparison of foliar and root metal uptake. - Journal of Hazardous Materials 325: 36-58.

[70] Shanker, A.K., Cervantes, C., Loza-Tavera, H., Avudainayagam, S. (2005): Chromium toxicity in plants. - Environment International 31: 739-753.

[71] Smiri, M. (2011): Effect of Cd on germination, growth, redox and oxidative properties in Pisum sativum seeds. - Journal of Environmental Chemistry and Ecotoxicology 3: 52-59.

[72] Sosa, M.C., Salazar, M.J., Zygadlo, J.A., Wannaz, E.D. (2016): Effects of Pb in Tagetes minuta L. (Asteraceae) leaves and its relationship with volatile compounds. - Industrial Crops and Products 82: 37-43.

[73] Sousa, A.C., Alviano, D.S., Blank, A.F., Alves, P.B., Alviano, A.F., Gattass, C.R. (2004): Melissa officinalis L. essential oil: antitumoral and antioxidant activities. - Journal of Pharmacy and Pharmacology 56: 677-681.

[74] Stewart, P., Globig, S. (2016): Photosynthesis: Research Progress in Botany; in Genetic, Environmental and Evolutionary Aspects. - Apple Academic Press. Inc. 3333, Mistwell, Crescent, Canada.

[75] Sussa, F.V., Duarte, C.L., Furlan, M.R., Silva, P.S.C. (2016): Agricultural management, season and trace elements effects on volatile oil production from Melissa officinalis L. (Lemon balm). - Journal of Radioanalytical and Nuclear Chemistry 307: 2365-2371.

[76] Tiwar, P. (2016): Recent advances and challenges in trichome research and essential oil biosynthesis in Mentha arvensis L. - Industrial Crops and Products 82: 141-148.

[77] Tomlinson, T.R., Akerele, O. (2015): Medicinal plants: their role in health and biodiversity. - University of Pennsylvania Press, Philadelphia.

[78] Um, C., Kurdmanee, C. (2009): Effect of salt stress on proline accumulation, photosynthetic ability and growth characters in two maize cultivars. - Pakistan Journal of Botany 41: 87-98.

[79] Wieczorek, J.K., Wieczorek, Z.J. (2007): Phytotoxicity and accumulation of anthracene applied to the foliage and sandy substrate in lettuce and radish plants. - Ecotoxicology and Environmental Safety 66: 369-377.

[80] Wolff, G., Pereira, G.C., Castro, E.M., Louzada, J., Coelho, F.F. (2012): The use of Salvinia auriculata as a bioindicator in aquatic ecosystem: biomass and structure dependent on the cadmium concentration. - Brazilian Journal of Biology 72: 71-77.

[81] Xu, Z., Zhou, G. (2008): Responses of leaf stomatal density to water status and its relationship with photosynthesis in a grass. - Journal of Experimental Botany 59: 33173325.

[82] Xu, P., Liu, D., Jiang, W. (2009): Cadmium effects on the organization of microtubular cytoskeleton in interphase and mitotic cells of Allium sativum. - Biologia Plantarum 53: 387-390.

[83] Yamori, W., Makino, A., Shikanai, T. (2016a): A physiological role of cyclic electron transport around photosystem I in sustaining photosynthesis under fluctuating light in rice. - Scientific Reports 6: 20147. 
[84] Yu, X., Liang, C., Chen, J., Qi, X., Liu, Y., Li, W. (2015): The effects of salinity stress on morphological characteristics, mineral nutrient accumulation and essential oil yield and composition in Mentha canadensis L. - Scientia Horticulturae 197:, 579-583.

[85] Zandalinas, S.I., Balfagón, D., Arbona, V., Gómez-Cadenas, A., Inupakutika, M.A., Mittler, R. (2016): ABA is required for the accumulation of APX1 and MBF1c during a combination of water deficit and heat stress. - Journal of Experimental Botany doi:10.1093/jxb/erw299

[86] Zhang, Z.S., Li, Y.T., Gao, H.Y., Yang, C., Meng, Q.W. (2016): Characterization of photosynthetic gas exchange in leaves under simulated adaxial and abaxial surfaces alternant irradiation. - Scientific Reports 6: 26963.

[87] Zouari, M., Elloumi, N., Ahmed, C., Delmail, D., Rouina, B., Abdallah, F., Labrousse, P. (2016): Exogenous proline enhances growth, mineral uptake, antioxidant defense, and reduces cadmium-induced oxidative damage in young date palm (Phoenix dactylifera L.). - Ecological Engineering 86: 202-209. 